OPEN ACCESS

Edited by:

Eric O. Young,

William H. Miner Agricultural Research Institute, United States

Reviewed by:

Federico Maggi,

University of Sydney, Australia Alan Tonin

University of Brasilia, Brazi

${ }^{*}$ Correspondence:

Gilles Pinay

gilles.pinay@irstea.fr

Specialty section: This article was submitted to

Soil Processes,

a section of the journal

Frontiers in Environmental Science

Received: 17 January 2018 Accepted: 22 May 2018

Published: 19 June 2018

Citation:

Pinay G, Bernal S, Abbott BW, Lupon A, Marti E, Sabater F and Krause S (2018) Riparian Corridors: A New Conceptual Framework for Assessing Nitrogen Buffering Across Biomes. Front. Environ. Sci. 6:47. doi: 10.3389/fenvs.2018.00047

\section{Riparian Corridors: A New Conceptual Framework for Assessing Nitrogen Buffering Across Biomes}

\author{
Gilles Pinay ${ }^{1 *}$, Susana Bernal ${ }^{2}$, Benjamin W. Abbott ${ }^{3}$, Anna Lupon ${ }^{4}$, Eugenia Marti ${ }^{2}$, \\ Francesc Sabater ${ }^{5}$ and Stefan Krause ${ }^{6}$ \\ ${ }^{1}$ Irstea Lyon, RiverLy, University of Lyon, Villeurbanne, France, ${ }^{2}$ Integrative Freshwater Ecology Group, Center for Advanced \\ Studies of Blanes (CEAB-CSIC), Blanes, Spain, ${ }^{3}$ Plant and Wildlife Sciences, Brigham Young University, Provo, UT, \\ United States, ${ }^{4}$ Department of Forest Ecology and Management, Swedish University of Agricultural Sciences, Umeå, \\ Sweden, ${ }^{5}$ Departament de Biologia Evolutiva, Ecologia i Ciències Ambientals, Universitat de Barcelona, Barcelona, Spain, \\ ${ }^{6}$ School of Geography, Earth and Environmental Sciences, University of Birmingham, Birmingham, United Kingdom
}

Anthropogenic activities have more than doubled the amount of reactive nitrogen circulating on Earth, creating excess nutrients across the terrestrial-aquatic gradient. These excess nutrients have caused worldwide eutrophication, fundamentally altering the functioning of freshwater and marine ecosystems. Riparian zones have been recognized to buffer diffuse nitrate pollution, reducing delivery to aquatic ecosystems, but nutrient removal is not their only function in river systems. In this paper, we propose a new conceptual framework to test the capacity of riparian corridors to retain, remove, and transfer nitrogen along the continuum from land to sea under different climatic conditions. Because longitudinal, lateral, and vertical connectivity in riparian corridors influences their functional role in landscapes, we highlight differences in these parameters across biomes. More specifically, we explore how the structure of riparian corridors shapes stream morphology (the river's spine), their multiple functions at the interface between the stream and its catchment (the skin), and their biogeochemical capacity to retain and remove nitrogen (the kidneys). We use the nitrogen cycle as an example because nitrogen pollution is one of the most pressing global environmental issues, influencing directly and indirectly virtually all ecosystems on Earth. As an initial test of the applicability of our interbiome approach, we present synthesis results of gross ammonification and net nitrification from diverse ecosystems.

Keywords: nitrogen cycling, buffering capacity, hydrosystem, river ecology, denitrification, nitrification, ammonification

\section{INTRODUCTION}

In his seminal paper "The stream and its valley," Hynes (1975) set the scene for an integrated approach to river systems, stipulating that rivers should not to be seen as aquatic ecosystems isolated from their terrestrial environment. Instead, rivers and streams both respond to and shape the catchment they drain. Despite Hynes' publication and Likens' innovative work at Hubbard Brook (Likens et al., 1970; Likens, 1984), riparian corridors have not been fully integrated into the 
conceptual models and methods of aquatic ecology, terrestrial ecology, or catchment hydrology, at least partially because of their intermediate (and methodologically awkward) status between aquatic and terrestrial environments. Two frameworks in stream ecology and fluvial morphology-the flood pulse concept (Junk et al., 1989) and the erosion-transition-deposition concepts (Leopold et al., 1964; Swanson et al., 1988; Church, 1992; Figure 1A) - consider riparian corridors and stream linkages from a physical perspective, emphasizing that river systems and their riparian zones are open ecosystems dynamically linked longitudinally, laterally, and vertically by hydrologic and geomorphic processes. Moreover, two central concepts in stream ecology-the river continuum concept (Vannote et al., 1980; Figure 1B) and nutrient spiraling theory (Webster, 1975; Newbold et al., 1981, 1983; Elwood et al., 1983; Minshall et al., 1983; Figure 1C) — have mostly considered the role of riparian corridors through their contribution to the organic matter supply in stream food-webs (but see Fisher et al., 1998). Yet, none of these concepts fully integrate riparian corridors with stream ecosystem functioning, or their role in controlling the diverse interactions between biotic and abiotic processes (Naiman and Décamps, 1997).

In this paper, we highlight the importance of taking longitudinal, lateral and vertical perspectives of riparian corridors into account to understand their functional role in landscapes. More specifically, we explore how the structure of riparian corridors shapes stream morphology (the river's spine), their multiple functions at the interface between the stream and its catchment (the skin), and their biogeochemical capacity to retain and remove nitrogen (the kidneys). Based on this background, we propose a new conceptual framework to test the capacity of riparian corridors to retain, remove, and transfer nitrogen along the continuum from land to sea under different climatic contexts. We focus on the nitrogen cycle for several reasons. First, nitrogen pollution is one of the most pressing global environmental issues, impacting virtually all ecosystems on Earth directly and indirectly (Steffen et al., 2015). Indeed, recent anthropogenic activities, including intensive agricultural and urbanization, have doubled reactive nitrogen circulating on the Earth, leading to excess nutrients transfer to freshwater ecosystems and ultimately causing the eutrophication of freshwater and marine aquatic ecosystems (Abbott et al., 2018b; Breitburg et al., 2018). Eutrophication causes anoxia, reduces aquatic biodiversity, decreases fish and shellfish stocks, and triggers harmful algal blooms with serious human health consequences (e.g., neurotoxins). Second, since the discovery of the nitrogen buffering capacity of riparian zones (Peterjohn and Correll, 1984), there has been much misplaced expectation that nutrient pollution could be solved with riparian corridors alone. To assess the true limits of riparian removal processes, common approaches across disciplines are needed. Third, most of the research on the nitrogen cycling in riparian zones is from temperate climatic conditions, which cannot be directly transferred to other biomes. Because the eutrophication crisis is truly global, affecting a broad variety of ecosystems from pole to pole, globally applicable methods and conceptual models are needed (Galloway et al., 2008;
Seitzinger et al., 2010). Hence, tackling the complex problem of worldwide eutrophication, largely due to diffuse nitrogen pollution, requires a catchment perspective along the river continuum.

\section{Riparian Corridors as the Spine of the River System}

Riparian corridors are both a consequence of and a constraint on hydrology and fluvial morphology. The morphology of stream channels and floodplains is governed by the volume, velocity, and timing of river discharge and sediment delivery, together with the geological and geomorphological characteristics and sediment properties of the drainage basin. These conditions influence the development of riparian vegetation, which in turn alters water balance (i.e., evapotranspiration), transmission of flood pulses, and water temperature. Along the river continuum, three distinct geomorphic sectors can be identified (Figure 1A). Headwaters are typically steep $(>4 \%)$ and occur in constrained valleys, resulting in high rates of erosion during floods, when coarse-grain particles can be mobilized. Narrow valley floors limit the accumulation of sediment, the development of riparian vegetation, and the size of riparian aquifers. In middle reaches of the river, there is a transition zone with decreasing gradient (between 4 and $1 \%$ ) and lower sediment transport. The existence of meanders, multiple channels, and islands within the river bed allow the development of larger riparian corridors on finer sediment deposits, increasing water residence time in these system components. The depositional sector corresponds to lowland valleys with fine unstable sediment deposits, where riparian vegetation develops in patches within unconstrained channels.

The erosion-transition-deposition concept demonstrates how terrestrial geomorphology (hillslope gradient) and stream hydrogeomorphic drivers (flood regime) influence the development of riparian zones. These physical constraints control the distribution of grain sizes as well as the successional dynamics and structure of vegetation communities along the river continuum (Gregory et al., 1991; Corenblit et al., 2007). In turn, riparian vegetation modifies local geomorphology and sediment dynamics (erosion, transport, and deposition) by providing resistance to flow and associated erosion (Gurnell and Petts, 2006). These reciprocal interactions between geomorphology and vegetation exist in all ecosystems, but their effects on landform dynamics are particularly pronounced in riparian corridors because of their intrinsically dynamic nature and contrasting hydrologic conditions. Hence, feedbacks between geomorphic, hydrologic, and vegetation processes can create a distinct mosaic of soil and sediment textures from headwaters to lowland floodplains. This "spine" or physical structure of riparian corridors is not only a mechanical filter of energy and matter, but it also modulates the lateral exchange of nutrients and organic matter, the spatial patterns of redox conditions, and consequently, the cycling of nitrogen as we will see in the following sections. 

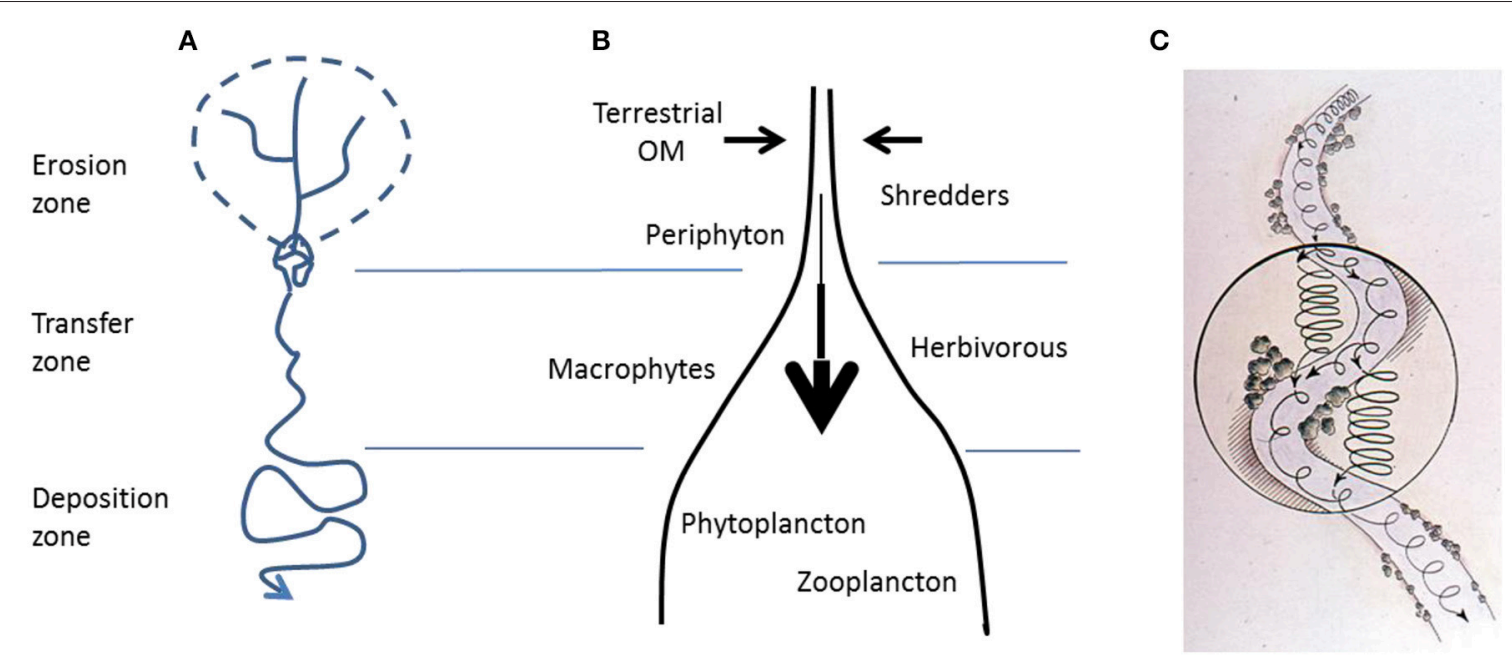

FIGURE 1 | (A) Erosion-transfer-deposition concept describing morphological regions along the river continuum. (B) River continuum concept predicting changes in biological communities along the longitudinal axis of rivers. (C) Nutrient spiraling concept. The spiral represents the cycling and transfer of nutrients and organic matter during its travel downstream. Tighter spiral represents faster cycling and longer residence time of nutrients or material in the riparian corridors compared to running waters (based data adapted from Vannote et al., 1980; Minshall et al., 1983; Church, 1992).

\section{Riparian Corridors act as a Skin for River Systems}

Analogously to the skin of vertebrate animals, riparian corridors act as semipermeable membranes that control the exchange of energy and matter between their surrounding environment and protect stream ecosystems from external disturbances. Riparian tree canopy regulates light and associated heat input to the stream, and roots protect river banks from erosion. Riparian vegetation slows flow during floods, causing sedimentation that maintains the floodplain. The riparian zone is not only an important source of organic matter and nutrients for streams and rivers-the unidirectional view already invoked by the river continuum concept (Figure 1B, Vannote et al., 1980)-but also a sink of these elements. Riparian zones are recipients of organic matter and nutrients from both stream and surrounding catchment, and these elements can be repeatedly mineralized, immobilized, or transported within and along riparian corridors. For instance, nutrient spiraling theory postulated that the interaction of stream water with adjacent riparian ecosystems can result in major changes in nutrient cycling and retention (Figure 1C, Minshall et al., 1983; Naiman and Décamps, 1990; Fisher et al., 1998). Since the 1980s, it has been known that riparian ecosystems have a large capacity to retain and remove nitrogen originating from upslope, highlighting their potential to regulate the exchange of material between terrestrial and aquatic ecosystems (Lowrance et al., 1984; Peterjohn and Correll, 1984; Jacobs and Gilliam, 1985; Burt et al., 2010 for a review). The bidirectional nature of the lateral exchange of material (from the catchment to the stream and vice versa) and their unique ecological and functional characteristics make riparian corridors quintessential ecotones (Naiman and Décamps, 1990).

Continuing with the skin metaphor, riparian corridors control the bidirectional exchange of energy and material between the stream and the catchment along the river continuum. These exchanges vary from headwaters to lowland floodplains in timing and magnitude depending on flood regime, predominant paths of delivery (i.e., surface, subsurface), and the form of elements delivered (i.e., particulate/dissolved, organic/mineral). In the upstream sections (erosion sectors), the transfer of carbon and nitrogen is dominated by inputs from the catchment to the stream (Abbott et al., 2018a), largely particulate and dissolved organic matter from riparian leaf litter and root inputs (Wallace et al., 2015). The transfer of dissolved nitrogen from uplands to the riparian zone via subsurface or deep groundwater flow can also be important, particularly in agricultural catchments. In the other direction, stream contributions to the riparian zone of particulate organic nitrogen can be substantial, but mainly during floods (Tabacchi et al., 1998; Pinay et al., 2002). Conversely, downstream sections (transition and deposition sectors) receive mostly dissolved and particulate organic and inorganic nitrogen from the stream, in particular during floods (Tabacchi et al., 1998; Pinay et al., 2002; Raymond et al., 2016). These downstream sections also receive dissolved nitrogen via subsurface flow through the hyporheic zone (Pinay et al., 1998; Kolbe et al., 2016). The lateral transfer of nitrogen from the upslope to the riparian corridors is very limited in these lower sections of the river. However, riparian corridors are not inert physical boundaries between aquatic and terrestrial environment, they also process the matter and energy during their transfer (Figure 1C). This functional component of the riparian corridors will be developed in the following section using nitrogen as an example.

\section{Riparian Corridors Function as Kidneys of River Systems}

In a landscape context, riparian corridors are analogous to kidneys because they filter surface and subsurface inputs 
and reduce sediment and contaminant transport (e.g., Mitsch and Gosselink, 2015). Regarding nitrogen, many studies after Peterjohn and Correll (1984) have shown the potential of riparian zones to recycle and remove part of the nitrogen loads received from both upstream and upslope ecosystems (Figure 1C). Despite the growing evidence at plot and field scales demonstrating the importance of floodplains on nitrogen cycling and removal, river systems have largely been considered as passive conduits of matter and energy from the catchments to the sea (Brookshire et al., 2009; Goodale et al., 2009). This view is certainly changing, and several recent syntheses based on mass balance analysis have revealed that river systems (including riparian zones) can permanently remove, or at least temporarily retain, part of the carbon, nutrients, and pollutants they receive from terrestrial ecosystems (Cole et al., 2007; Bernal et al., 2015, 2018). For instance, freshwater ecosystems cover $<3 \%$ of the global land surface, but receive 3.7-4.5 $\mathrm{Pg} \mathrm{C} \mathrm{yr}^{-1}$ from terrestrial ecosystems; a flux similar in magnitude to the total global land sink (Aufdenkampe et al., 2011). Streams, rivers, lakes, and wetlands outgas $2.1 \mathrm{Pg}$ of this carbon as carbon dioxide $\left(\mathrm{CO}_{2}\right)$, and sequester from 0.5 to $1.5 \mathrm{Pg}$ in sediment. These global estimates suggest that $<25 \%$ of terrestrial carbon input reaches the ocean and that river networks can play a fundamental role on the global carbon cycle (Raymond et al., 2013).

Some of natural and anthropogenic nitrogen is recycled and retained in upland soils (Sébilo et al., 2013; Van Meter and Basu, 2017), but a significant proportion is transferred to riparian and aquatic ecosystems (Abbott et al., 2018b). The high metabolic activity of riparian zones contributes to both high nitrogen retention via biological assimilation, long term storage in riparian soils, and high nitrogen removal during transit from land to sea, especially via denitrification (Boyer et al., 2006). However, this filtering capacity can be partially counterbalanced by organic matter mineralization that can liberate nitrogen, particularly in nitrogen saturated ecosystems (Sabater et al., 2003; Taylor and Townsend, 2010). In fact, carbon and nitrogen cycles are fundamentally coupled in aquatic and terrestrial ecosystems, and the quality of organic matter and $\mathrm{C}: \mathrm{N}$ ratios can profoundly influence nitrogen cycling. Microbes can mineralize carbon and assimilate nitrogen when carbon is not limiting (C:N ratios in excess microbial metabolic need), while nitrification and denitrification are favored when nitrogen is abundant and the C:N ratio is below microbial demand (Taylor and Townsend, 2010). These stoichiometric constraints result in a trade-off between organic carbon concentration and mineral nitrogen concentration (both of which can cause water quality problems), with both ammonia and nitrate decreasing when organic carbon is abundant (Taylor and Townsend, 2010). This general pattern appears to hold across a wide range of terrestrial and aquatic ecosystems, suggesting that large inputs of nitrogen or carbon to floodplain systems could change substrate stoichiometry and impact ecosystem respiration and nitrogen retention and removal. For instance, Rosemond et al. (2015) found that average residence time of terrestrially-derived particulate organic carbon decreased by half under high nitrogen availability during a long-term experiment manipulating loworder streams with various nitrogen applications. Under anoxic conditions, however, stoichiometric constraints of carbon and nitrogen supply are often secondary to redox conditions in controlling overall nitrogen uptake and loss (Helton et al., 2015). This is because nitrate is not only used by organisms as a nutrient source (assimilation), but also as electron acceptor in the place of oxygen during denitrification (dissimilation). Thus, low redox can lead to decreases in nitrate when organic carbon availability is high, though lack of oxygen can also lead to ammonia accumulation due to the absence of nitrification (Hedin et al., 1998; Helton et al., 2015).

Stoichiometric and redox controls on nitrogen retention and removal, and thus the role of riparian corridors as kidneys of river systems, can shift along the lateral and longitudinal axes from headwaters to lowland floodplains (Tabacchi et al., 1998). Because riparian corridors occur in downslope landscape positions, they accumulate fine sediment, near-surface soil water, and groundwater flowpaths (McClain et al., 2003), setting the stage for high rates of biogeochemical processes including gross nitrogen mineralization, nitrification, and denitrification compared to the rest of the catchment (Brinson et al., 1984; Brinson, 1993; Hedin et al., 1998). However, the balance between these different biogeochemical processes depends on a suite of environmental conditions in the riparian zone such as nitrogen supply, substrate stoichiometry, and hydrologic regime (e.g., floods, water table position). Differences in the frequency and duration of flood events between the erosion, transition, and depositional sectors and in the associated redox conditions can influence the nitrogen cycle in riparian corridors, creating distinct mosaics of oxic and anoxic conditions prone to nitrification and denitrification processes, respectively (Hefting et al., 2004; Abbott et al., 2018a). Shorter flood periods in the upstream sections would lead to more spatially homogenous redox conditions compared to the downstream parts, where less frequent but longer events favor the development of local anoxia in a heterogeneous geomorphic context.

The distribution of soil and sediment texture also contributes to the spatial heterogeneity of redox conditions and thus, mediates denitrification activity. A paired study comparing riparian soils with different texture but exposed to the same flood regime showed minimal denitrification for $<65 \%$ of silt and clay content, while above that threshold, denitrification increased linearly (Pinay et al., 1995, 2000). Similarly, significant nonlinear relationships have been also found, for instance, between denitrification rates and soil texture in floodplains across Europe and elsewhere, with fine textured soils (i.e., high in silt and clay) being more prone to denitrification (e.g., Pinay et al., 2007; Malone et al., 2018). These examples highlight that geomorphic conditions and the configuration of soil textures associated with flood regime and vegetation structure (the spine), together with the bidirectional lateral exchange of materials (the skin), control gaseous, and hydrological nitrogen losses, ultimately influencing nitrogen retention in riparian soils and sediments.

\section{A Way Forward: A New Concept of the Potential for Nitrogen Retention and Supply Along the Riparian Continuum}

By now, you hopefully agree with us that riparian corridors are key landscape elements, regulating continental nitrogen 
transfer to the atmosphere and oceans. Yet, even for the converted, the high spatiotemporal variability of interactions between physical and biological processes at the reach scale still hampers scaling up processes such as nitrogen retention or removal to larger scales (Groffman et al., 2006; Pinay et al., 2015). Moreover, the variability of environmental conditions and rates of nitrogen processing within riparian corridors are even more daunting when comparing systems from different climatic regions (Décamps et al., 2004). While riparian zones have been well-studied in temperate regions, in other regions there is evidence that riparian corridors may function fundamentally differently concerning carbon and nutrient dynamics (e.g., Bernal et al., 2007). Therefore, we are left with a paradox: multiscale and cross biome understanding is needed but comprehensive study of the different processes involved in riparian nitrogen cycling is only feasible at relatively small plot scales. Indeed, so far, the evaluation of the buffering capacity of riparian zones has focused on very detailed, small-scale hydrological and biogeochemical assessments, which revealed that removal capacity is intrinsically dependent on the ratio between the residence time of nitrate in the riparian zone and the denitrification rate (i.e., the Damköhler ratio; Sabater et al., 2003; Ocampo et al., 2006; Oldham et al., 2013; Pinay et al., 2015). Yet, simply examining the variability of a particular process (e.g., denitrification) at relatively small scales does not adequately quantify the potential of riparian corridors to buffer nitrogen inputs or supply nitrogen to stream food webs at catchment scale.

Because anthropogenic inputs of reactive nitrogen to aquatic ecosystems are increasing all over the world, there is an urgent need to evaluate the intrinsic capacity of riparian zones to retain or remove nitrogen. In the final section of this paper, we argue that this evaluation needs to be done along the river continuum because, as explained above, biogeochemical processes are controlled by hydro-geomorphic drivers, which vary from small headwater streams to large lowland rivers (Thomas et al., 2016). Therefore, we need to develop a comparative approach across biomes to evaluate the intrinsic capacity of riparian corridors to buffer nitrogen loads under different climatic conditions.

In this context, we propose that the capacity for nitrogen retention, removal, and transport of riparian corridors both along the river continuum and under different climatic conditions could be meaningfully characterized using gross ammonification and net nitrification. These two essential processes of the nitrogen cycle together are indices of inorganic nitrogen inputs and outputs. The associated methods are well-known and widely used in soil science, but have been less implemented in riparian zones, with the notable exception of Brinson et al. (1984), who used long-term nutrient additions to evaluate the nutrient assimilative capacity of an alluvial floodplain swamp. Although measurements of gross nitrification and net nitrification cannot quantify the realized in situ buffering capacity of riparian zones, they allow comparison of potential buffering and leaching across stream orders and biomes.

Gross ammonification (Figure 2) is the total amount of organic nitrogen mineralized into ammonium (Hart et al., 1994), and is therefore an indicator of the amount of nitrogen available for biological uptake, microbial transformation (gross nitrification), and removal from the ecosystem as gas products via nitrification and denitrification. Anammox, the conversion of ammonium and nitrite to nitrogen gas under anaerobic conditions, is believed to play a minimal role in the riparian nitrogen cycle (Hamilton et al., 2016), though this assumption

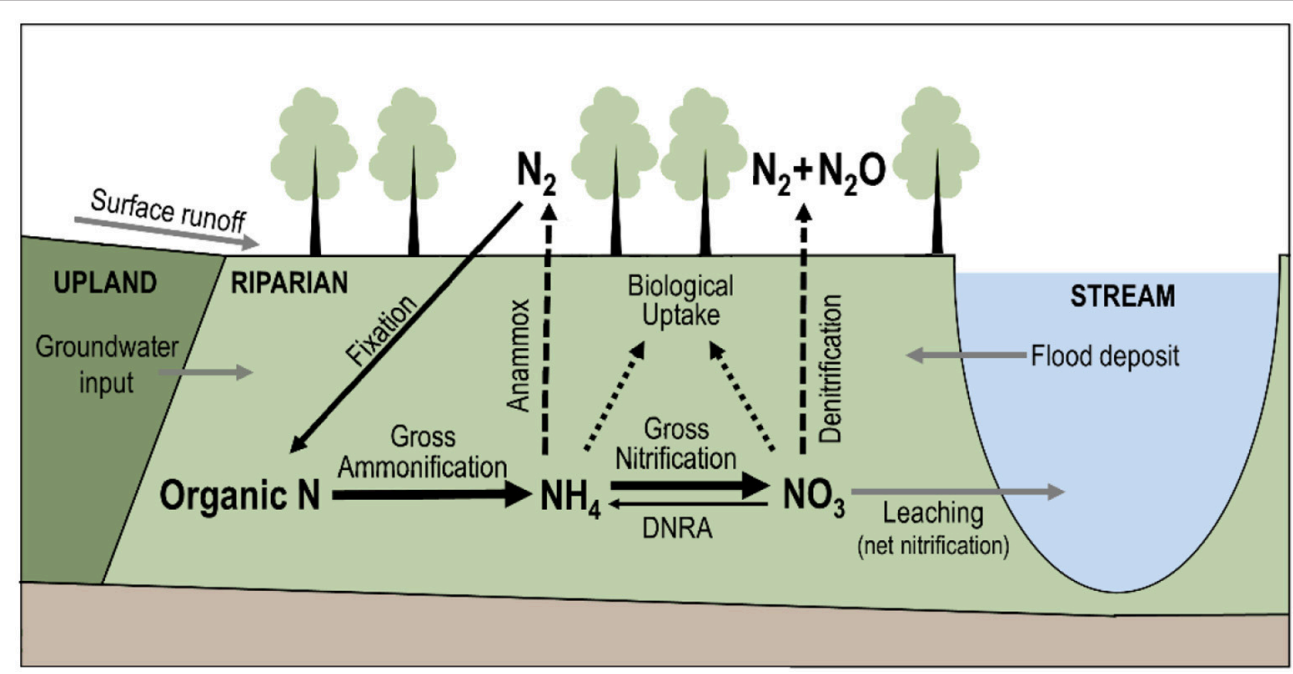

FIGURE 2 | Schematic representation of the nitrogen cycle in riparian corridors. Solid, dashed, and dotted arrows represent, respectively, processes that transform, remove, and retain nitrogen from the riparian soil. Briefly, inorganic nitrogen is produced in the riparian soil via gross ammonification. The proportion of ammonium $\left(\mathrm{NH}_{4}^{+}\right)$and nitrate $\left(\mathrm{NO}_{3}^{-}\right)$in the soil depends on gross nitrification and dissimilatory nitrate reduction (DNRA). Outputs of inorganic nitrogen from the riparian soil are assimilatory uptake by biota (i.e., retention), anammox, denitrification (only for nitrate), and leaching toward the stream. Therefore, net nitrification can be a proxy of the potential nitrogen loss of riparian corridors. Moreover, the hydrological connections between uplands, riparian corridors, and streams can transport nitrogen from one system to the other (gray arrows). 
may be worth testing in some environments. In most ecosystems, mineralization of organic matter is the primary source of nitrogen, and the availability of nitrogen determines the rate of primary production (Vitousek and Field, 1999). The link between ammonification (mineralization) and primary production (plant growth) is less direct in extremely nitrogen-rich environments, such as agricultural catchments where anthropogenic fertilizers are the major nitrogen source, or in extremely nitrogenpoor environments, where plants can directly take up some organic nitrogen compounds (Schimel and Bennett, 2004). But extreme cases aside, gross ammonification is a proxy of primary production. Gross ammonification can be estimated by isotopic dilution methods (Hart et al., 1994), and can be compared for instance to remotely-sensed estimates of net plant production to relate biomass accrual to nitrogen uptake by vegetation (Pettorelli et al., 2005).

Net nitrification (Figure 2) is a useful complement to gross ammonification because it indicates the amount of nitrate remaining in the system after biological uptake. Net nitrification rates can be high even in mature forest systems (Stark and Hart, 1997), leading to gaseous losses during nitrification but mostly during denitrification, which is a dissimilatory anaerobic pathway (see Burt et al., 2010 for a review). Net rates of nitrification can be calculated from the changes of nitrate pool sizes over the course of in situ incubation of soils samples in polyethylene bags for several weeks (Eno, 1960; Malone et al., 2018) or even a day (Ross et al., 2006). Such measurement of net nitrification is only a potential rate (Hart et al., 1994) and can be interpreted as a proxy of potential nitrate contribution to the subjacent soil or adjacent stream (Ross et al., 2012).

Therefore, the potential for nitrogen retention potential (plant and microbial uptake) and/or removal (denitrification) of the riparian system can be inferred from the difference between gross ammonification and net nitrification. Moreover, the difference between gross ammonification and biological uptake, which could be estimated by net biomass accrual, could be used as an approximation of the potential nitrogen loss of riparian corridors, either by denitrification or leaching. Whether nitrate will be lost as gas to the atmosphere, or leached as nitrate laterally will ultimately depend on soil or sediment redox conditions.

These functional properties, i.e., primary production, nitrogen removal capacity, and inorganic nitrogen supply to aquatic food webs, are key features of riparian systems that have primarily been quantified individually and mostly at the reach scale. Estimating these key processes together along the river continuum and across climatic gradients would greatly improve our understanding of how potential nitrogen retention, removal and transfer to aquatic ecosystems are spatially organized in nested catchments of the Earth. This would provide a basis for predicting which of these processes vary in response to climate change (i.e., temperature and hydrological cycles) and anthropogenic disturbance (i.e., increasing nutrient loading or disturbance). Studies available in the literature support the idea that the potential for nitrogen retention of riparian soils could vary greatly across biomes. In our meta-analysis of published gross ammonification in riparian zones, we found substantial differences among climatic regions, with gross ammonification inversely related to aridity (Figure 3). Broadly, rates of gross ammonification range from 1-4 mg N/kg soil/day in dry systems (MAP < $600 \mathrm{~mm}$; Shaw and Harte, 2001; Stark and Norton, 2015) to $8-10 \mathrm{mg} \mathrm{N} / \mathrm{kg}$ soil/day and $>15 \mathrm{mg} \mathrm{N} / \mathrm{kg}$ soil/day in temperate and tropical systems (MAP $>1,000$ and 2,000 mm, respectively; Purwanto et al., 2005; Matheson et al., 2012). In contrast, net nitrification rates in riparian soils show an optimum under mediterranean climatic conditions (Figure 3).

As a basis for discussion and debate, we present a conceptual figure describing how gross ammonification, net nitrification, plant uptake, and denitrification could differ along river continuums and biomes (Figure 4). This conceptual figure is based on some published evidences and our own expertise, and represents a first attempt at describing general patterns, which need to be challenged with real data in future studies. Among the lines of evidence, we know that the size of riparian forests tends to increase from upstream to downstream sections due to topographic constraints, potentially increasing primary production and associated nitrogen uptake and carbon production along the river continuum. This idea is supported by general patterns of increasing mineralization along the stream network associated with a shift toward fine-textured

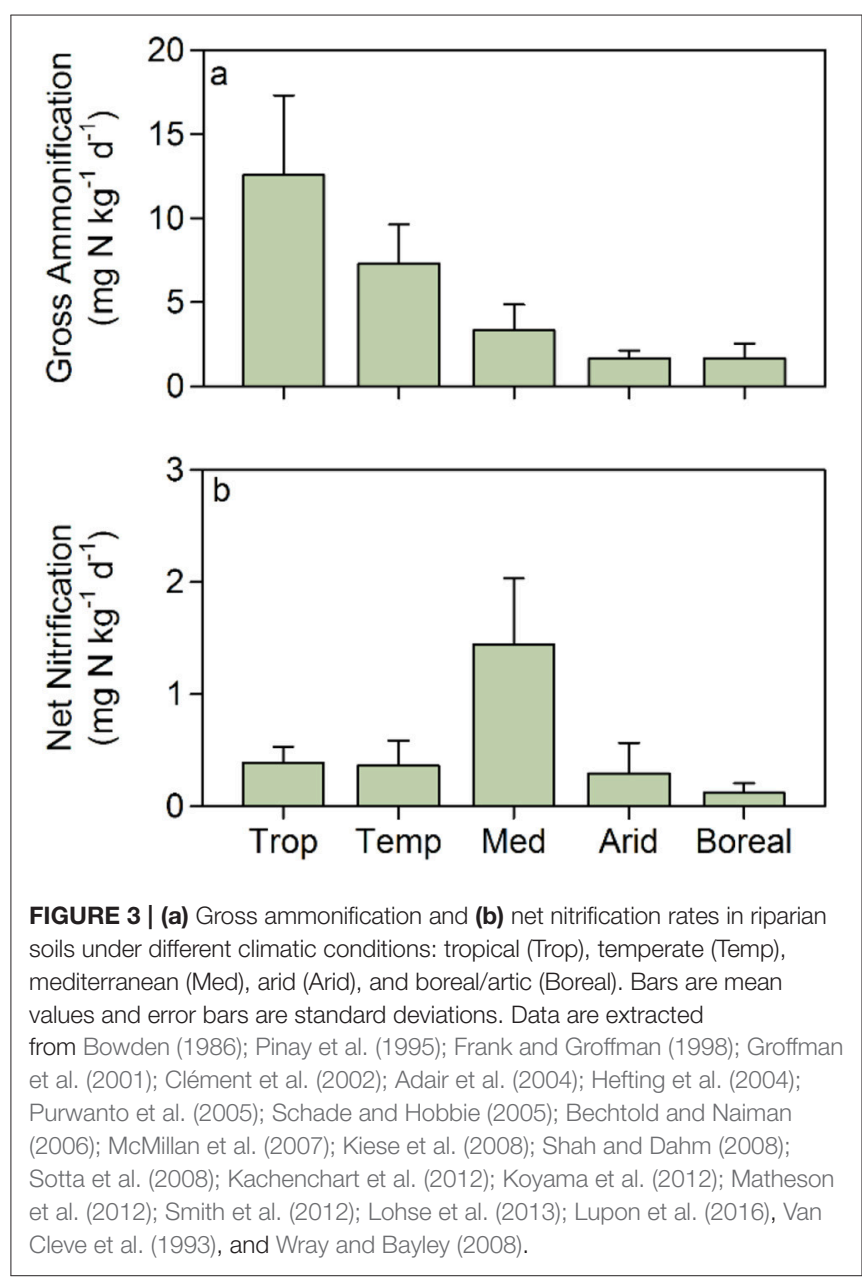



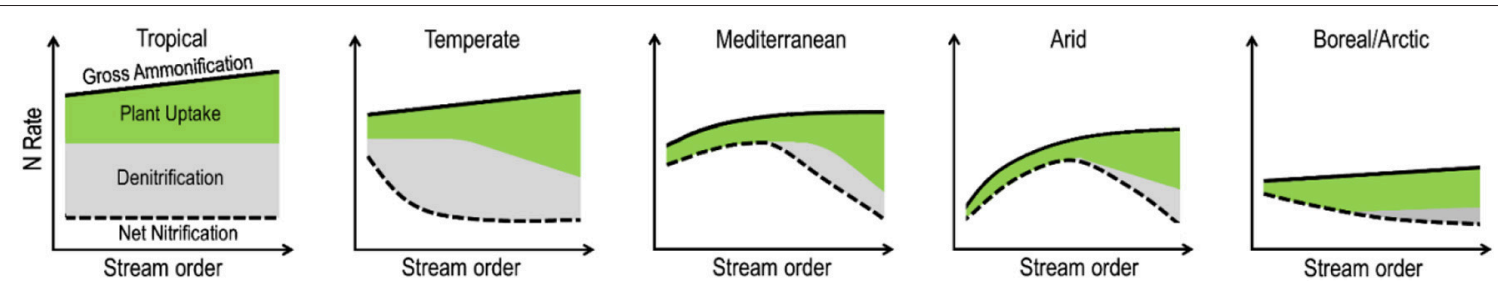

FIGURE 4 | Conceptual representation of gross ammonification (solid black line), net nitrification (dashed black line), plant uptake (green surface), and denitrification (gray surface) in riparian corridors along river continuum under different climatic conditions. Explanations for these hypothesized trajectories are given in the text.

soils (Evans and Schoenholtz, 2011; Noe et al., 2013). There is also evidence that changes in soil texture and soil moisture content along riparian corridors can influence their nitrogen removal potential, which tends to increase in the transition and depositional sections as compared to erosional sections (Noe et al., 2013). As with mineralization, the potential for nitrogen retention and removal can vary dramatically between climatic regions, especially because denitrification, one of the main processes responsible for nitrogen removal, is highly dependent on soil moisture conditions and nitrate supply. In tropical and temperate regions, denitrification can account for up to half of the total ecosystem nitrogen losses (Hefting et al., 2004; Houlton et al., 2006; Fang et al., 2015). We hypothesize that denitrification represents a significant part of the $\mathrm{N}$ cycling in tropical riparian zones, whatever the stream order (McClain et al., 1994; Décamps et al., 2004; Houlton et al., 2006). Indeed constant humid conditions maintain soil moisture to a high percentage of saturation promoting the coexistence of aerobic and anaerobic microsites, which favor both nitrification and denitrification (Hefting et al., 2004). Under temperate conditions, strong seasonal shifts in rainfall and soil moisture patterns entail a decrease in denitrification activity in riparian zones along larger streams (Pinay et al., 1995, 2000; Tabacchi et al., 1998). Based on existing published data, we forecast that denitrification is not significant in riparian zones along low stream order streams under Mediterranean, arid or arctic climate due to low water availability and/or short residence time of water and solutes (Jones et al., 2005; Bernal et al., 2007; Mu et al., 2017; Poblador et al., 2017). Therefore, we forecast that in Mediterranean and arid regions, denitrification rates are consistently low compared to more humid catchments (Holmes et al., 1996; Bernal et al., 2007; Harms and Grimm, 2010; Lupon et al., 2015; Poblador et al., 2017). Yet, the capacity for denitrification can rapidly increase once waterlogged conditions develop in riparian zones (Harms et al., 2009). Indeed, along larger stream orders under these climatic conditions, soil development, including accretion of fine sediment texture and organic matter increase the water residence time and in turn denitrification capacity (Fang et al., 2015; Tiwari et al., 2017; Malone et al., 2018). We recognize that many ecological and climatological dynamics interrupt these broad patterns, which we present only as general predictions to be tested across biomes.

Our hypotheses about nitrogen cycling in arctic and boreal riparian zones are particularly speculative due to relatively few studies compared to other biomes and typically low nitrogen concentrations which can limit parameterization of some of these processes. Boreal systems are characterized by very low temperatures, short growing seasons, and low mean annual precipitation (MAP $=600-800 \mathrm{~mm}$ ). Boreal and arctic regions are also characterized by extreme nutrient limitation and episodic water and elemental flux due to long periods of subzero temperature and large spring floods (Petrone et al., 2006; Holmes et al., 2012). Because inorganic nitrogen concentrations are so low, nitrogen-fixing riparian vegetation (e.g., Alnus sp. or Dryas sp.) often dominates floodplains, increasing carbon and nitrogen availability simultaneously, as water moves downstream (Ruess et al., 2013; Taylor, 2013; Malone et al., 2018). Furthermore, headwater aquatic primary production (algae) is often phosphorus limited, resulting in rapid nitrification of what little ammonium makes it to the stream channel, though nitrogen demand increases as rivers meet the sea (Holmes et al., 2012; McClelland et al., 2012). There is evidence that rapid climate change at high latitudes and associated permafrost degradation are increasing nitrogen availability and potentially induce shifts in the nitrogen cycle (Jones et al., 2005; Abbott et al., 2015; Voigt et al., 2017). Particularly, increased nutrient delivery to riparian zones and stream networks from degrading permafrost could enhance or suppress nitrogen uptake depending on the nutrient stoichiometry. Denitrification, which is currently low or absent in many arctic and boreal systems, could increase due to higher available nitrogen in conjunction with extremely biodegradable carbon inputs from permafrost degradation (Abbott et al., 2014; Larouche et al., 2015).

We hypothesize that the potential for nitrogen retention and/or removal of riparian zones increases with stream order regardless of latitude. This idea is supported by the erosion-transition-deposition concept, the distribution of soil and sediment textures along the river continuum, and the relationship between denitrification and content of silt and clay. This statement is also supported by the few examples of longitudinal variations in microbial rates reported in the literature. For instance, Noe et al. (2013) reported significant differences in ammonification and nitrification rates between riparian plots located in 4 th vs. 5th stream orders. In particular, ammonification rates in riparian soils increased along the stream network (likely due to high clay content), but nitrification rates decreased as soil moisture content increased in the 5th order floodplains. A possible exception to this general trend is so-called 0 -order streams at the terrestrial-aquatic transition, which often 
have high retention capacity (Harms and Ludwig, 2016) due to longer residence times and local accumulation of fine sediment.

Despite the existence of multiple lines of evidence, there are still severe knowledge gaps, and data is lacking especially from high and low-latitude ecosystem. Moreover, the impact of climate change and anthropogenic pressures on the buffering capacity of riparian corridors at local and regional scales remain highly uncertain. We acknowledge that the trajectories depicted in Figure $\mathbf{4}$ are hypothetical and need to be confronted with real data. Yet, the objective of this intellectual exercise is to encourage readers to challenge the proposed ideas by undertaking systematic and comparable measurements of gross ammonification, plant accrual, and net nitrification along stream orders and biomes. The elaboration of sound data-based global pattern of riparian zone retention, removal, and transfer of nitrogen would acknowledge that riparian zone removal potential in different regions varies in magnitude and sign, and will certainly respond differently to both climatic and anthropogenic pressures.

\section{CONCLUSIONS}

Anthropogenic and climatic changes all over the planet call for a comparable approach to quantify the role of riparian zones in different biomes in order to predict the impacts of these changes on stream ecosystem functioning and water quality. This manuscript reviews the gradual interest in riparian zone functioning over the last 40 years and stresses the riparian corridor as a key structural component of stream ecosystems, but also as interface between the catchment and its draining streams. We acknowledge that so far, most research and modeling

\section{REFERENCES}

Abbott, B. W., Gruau, G., Zarnetske, J. P., Moatar, F., Barbe, L., Thomas, Z., et al. (2018a). Unexpected Spatial stability of water chemistry in headwater stream networks. Ecol. Lett. 21, 296-308. doi: 10.1111/ele.12897

Abbott, B. W., Jones, J. B., Godsey, S. E., Larouche, J. R., and Bowden, W. B. (2015). Patterns and persistence of hydrologic carbon and nutrient export from collapsing upland permafrost. Biogeosciences 12, 3725-3740. doi: 10.5194/bg-12-3725-2015

Abbott, B. W., Larouche, J. R., Jones, J. B., Bowden, W. B., Balser, A. W., et al. (2014). Elevated dissolved organic carbon biodegradability from thawing and collapsing permafrost: Permafrost carbon biodegradability. J. Geophys. Res. Biogeosci. 119, 2049-2063. doi: 10.1002/2014JG002678

Abbott, B. W., Gruau, G., Zarnetske, J. P., Moatar, F., Barbe, L., Thomas, Z., et al. (2018b). Trends and seasonality of river nutrients in agricultural catchments: 18 years of weekly citizen science in France. Sci. Total Environ. 624, 845-858. doi: 10.1016/j.scitotenv.2017.12.176

Adair, E. C., Binkley, D., and Andersen, D. C. (2004). Patterns of nitrogen accumulation and cycling in riparian floodplain ecosystems along the Green and Yampa rivers. Oecologia 139, 108-116. doi: 10.1007/s00442-004-1486-6

Aufdenkampe, A. K., Mayorga, E., Raymond, P. A., Melack, J. M., Doney, S. C., Alin, S. R., et al. (2011). Riverine coupling of biogeochemical cycles between land, oceans, and atmosphere. Front. Ecol. Environ. 9, 53-60. doi: 10.1890/100014

Bechtold, J. S., and Naiman, R. J. (2006). Soil texture and nitrogen mineralization potential across a riparian toposequence in a semi-arid savanna. Soil Biol. Biochem. 38, 1325-1333. doi: 10.1016/j.soilbio.2005.09.028 have focused on temperate regions (Décamps et al., 2004). Recent work on other biomes reveal some commonalities, but also significant differences in key processes, notably related to energy and matter cycling. Moreover, the position along the river continuum is likely to influence riparian zone functioning.

Here, we propose a conceptual model and a set of hypothesis regarding changes in riparian primary production, nitrogen removal capacity, and inorganic nitrogen supply to stream food webs across stream orders and biomes. To test this hypothesis, we suggest the systematic analysis of a series of proxies such as gross ammonification, vegetation accrual and net nitrification, which are relatively easy to estimate by using well-known empirical methods. Quantifying these key processes along river continuum and across climatic gradients will provide valuable insight into how riparian zones will respond to climate change and anthropogenic disturbances.

\section{AUTHOR CONTRIBUTIONS}

GP initiated the work and all the co-authors equally contributed to the discussion and writing the manuscript.

\section{ACKNOWLEDGMENTS}

The authors wish to acknowledge funding from the EU-FP7PEOPLE programme for the INTERFACES Initial Training Network (FP7-PEOPLE-2013-ITN, grant no. 607150). GP and BA were also supported by the French National Programme EC2CO Continental and Coastal Ecosphere, as well as the Rennes Métropole installation grant. SB was funded by the MINECO project NICUS (CGL-2014-55234-JIN). AL was supported by a Kempe Foundation stipend.

Bernal, S., Lupon, A., Catalán, N., Castelar, S., and Martí, E. (2018). Decoupling of dissolved organic matter patterns between stream and riparian groundwater in a headwater forested catchment. Hydrol. Earth Syst. Sci. 22, 1897-1910. doi: 10.5194/hess-22-1897-2018

Bernal, S., Lupon, A., Ribot, M., Sabater, F., and Martí, E. (2015). Riparian and instream controls on nutrient concentrations and fluxes in a headwater forested stream. Biogeosciences 12, 1941-1954. doi: 10.5194/bg-12-1941-2015

Bernal, S., Sabater, F., Butturini, A., Nin, E., and Sabater, S. (2007). Factors limiting denitrification in a Mediterranean riparian forest. Soil Biolo. Biochem. 39, 2685-2688. doi: 10.1016/j.soilbio.2007. 04.027

Bowden, W. B. (1986). Nitrification, nitrate reduction, and nitrogen immobilization in a tidal freshwater marsh sediment. Ecology 67, 88-99. doi: $10.2307 / 1938506$

Boyer, E. W., Alexander, R. B., Parton, W. J., Li, C., Butterbach-Bahl, K., Donner, S. D., et al. (2006). Modeling denitrification in terrestrial and aquatic ecosystems at regional scales. Ecol. Appl. 16, 2123-2142. doi: 10.1890/10510761(2006)016[2123:MDITAA]2.0.CO;2

Breitburg, D., Levin, L. A., Oschlies, A., Grégoire, M., Chavez, F. P., Conley, D. J., et al. (2018). Declining oxygen in the global ocean and coastal waters. Science 359:eaam7240. doi: 10.1126/science.aam7240

Brinson, M. M. (1993). Changes in the functioning of wetlands along environmental gradients. Wetlands 13, 65-74. doi: 10.1007/BF031 60866

Brinson, M. M., Bradshaw, H. D., and Kane, E. S. (1984). Nutrient assimilative capacity of an alluvial floodplain swamp. J. Appl. Ecol. 21, 1041-1057. doi: $10.2307 / 2405066$ 
Brookshire, E. N. J., Valett, H. M., and Gerber, S. G. (2009). Maintenance of terrestrial nutrient loss signatures during instream transport. Ecology 90, 293-299. doi: 10.1890/08-0949.1

Burt, T. P., Pinay, G., and Sabater, S. (2010). Riparian Zone Hydrology and Biogeochemistry. Wallingford, UK: IAHS Benchmark Papers in Hydrology Series.

Church, M. (1992). "Channel Morphology and typology," in The River Handbook: Hydrological and Ecological Principles, Vol. 1, eds P. Calow and G. E. Petts (Oxford: Blackwell), 126-143.

Clément, J. C., Pinay, G., and Marmonier, P. (2002). Seasonal dynamics of denitrification along topohydrosequences in three different riparian wetlands. J. Environ. Qual. 31, 1025-1037. doi: 10.2134/jeq2002.1025

Cole, J. J., Prairie, Y. T., Caraco, N. F., McDowell, W. H., Tranvik, L. J. Striegl, R. G., et al. (2007). Plumbing the global carbon cycle: integrating inland waters into the terrestrial carbon budget. Ecosystems 10, 171-184. doi: 10.1007/s10021-006-9013-8

Corenblit, D., Tabacchi, E., Steiger, J., Gurnell, A. M. (2007). Reciprocal interactions and adjustments between fluvial landforms and vegetation dynamics in river corridors: a review of complementary approaches. Earth Sci. Rev. 84, 56-86. doi: 10.1016/j.earscirev.2007.05.004

Décamps, H., Pinay, G., Naiman, R. J., Petts, G. E., McClain, M. E., HillbrichtIlkowska, A. H. T. A., et al. (2004). Riparian zones: where biogeochemistry mets biodiversity in management practice. Pol. J. Ecol. 52, 3-18.

Elwood, J. W., Newbold, J. D., O’Neill, R. V., and Van Winkle, W. (1983). “Resource spiraling: an operational paradigm for analyzing lotic ecosystems," in Dynamics of Lotic Ecosystems, eds T. D. Fontaine, and S. M. Bartell (Ann Arbor, MI: Ann Arbor Science), 3-27.

Eno, C. F. (1960). Nitrate production in the field by incubating the soil in polyethylene bags. Soil Sci. Soc. Am. J. 24, 277-279. doi: 10.2136/sssaj1960.03615995002400040019x

Evans, D. M., and Schoenholtz, S. H. (2011). Nitrogen mineralization in riparian soils along a river continuum within a Multi-Land-Use basin. Soil Sci. Soc. Am. J. 75, 719-728. doi: 10.2136/sssaj2010.0162

Fang, Y., Koba, K., Makabe, A., Takahashi, C., Zhu, W., Hayashi, T., et al. (2015). Microbial denitrification dominates nitrate losses from forest ecosystems. Proc. Natl. Acad. Sci. U.S.A. 112, 1470-1474. doi: 10.1073/pnas.1416776112

Fisher, S. G., Grimm, N. B., Marti, E., Holmes, R. M., and Jones, J. B. Jr. (1998). Material spiraling in stream corridors: A telescoping ecosystem model. Ecosystems 1, 19-34. doi: 10.1007/s100219900003

Frank, D. A., and Groffman, P. M. (1998). Ungulate vs. landscape control of soil $\mathrm{C}$ and $\mathrm{N}$ processes in grasslands of Yellowstone National Park. Ecology 79, 2229-2241. doi: 10.1890/0012-9658(1998)079[2229:UVLCOS]2.0.CO;2

Galloway, J. N., Townsend, A. R., Erisman, J. W., Bekunda, M., Cai, Z., Freney, J. R., et al. (2008). Transformation of the nitrogen cycle: recent trends, questions, and potential solutions. Science 320, 889-892. doi: 10.1126/science.1136674

Goodale, C. L., Thomas, S. A., Fredriksen, G., Elliott, E. M., Flinn, K. M., Butler, T. J., et al. (2009). Unusual seasonal patterns and inferred processes of nitrogen retention in forested headwaters of the Upper Susquehanna River. Biogeochemistry 93, 197-2018. doi: 10.1007/s10533-009-9298-8

Gregory, S. V., Swanson, F. J., McKee, W. A., Cummins, K. W. (1991). An ecosystem perspective of riparian zones. Bioscience 41, 540-551. doi: $10.2307 / 1311607$

Groffman, P. M., Altabet, M. A., Böhlke, J. K., Butterbach-Bahl, K., David, M. B., Firestone, M. K., et al. (2006). Methods for measuring denitrification: diverse approaches to a difficult problem. Ecol. Appl. 16, 2091-2122. doi: 10.1890/10510761(2006)016[2091:MFMDDA]2.0.CO;2

Groffman, P. M., McDowell, W. H., Myers, J. C., and Merriam, J. L. (2001). Soil microbial biomass and activity in tropical riparian forests. Soil Biol. Biochem. 33, 1339-1348. doi: 10.1016/S0038-0717(01)00039-6

Gurnell, A. M., and Petts, G. E. (2006). Trees as riparian engineers: the Tagliamento River, Italy. Earth Surface Process. Landforms 31, 1558-1574. doi: 10.1002/esp.1342

Hamilton, L., Trimmer, M., Bradley, C., and Pinay, G. (2016). Deforestation for oil palm alters the fundamental balance of the soil N cycle. Soil Biol. Biochem. 95, 223-232. doi: 10.1016/j.soilbio.2016.01.001

Harms, T. K., and Grimm, N. B. (2010). Influence of the hydrologic regime on resource availability in a semi-arid stream-riparian corridor. Ecohydrology 3, 349-359. doi: 10.1002/eco.119
Harms, T. K., and Ludwig, S. M. (2016). Retention and removal of nitrogen and phosphorus in saturated soils of arctic hillslopes. Biogeochemistry 127, 291-304. doi: 10.1007/s10533-016-0181-0

Harms, T. K., Wentz, E. A., and Grimm, N. B. (2009). Spatial heterogeneity of denitrification in semi-arid floodplains. Ecosystems 12, 129-143. doi: $10.1007 /$ s10021-008-9212-6

Hart, S., Stark, J., Davidson, E., and Firestone, M. K. (1994). "Nitrogen mineralization, immobilization, and nitrification," in Methods of Soil Analysis, Microbiological and Biochemical Properties, Part 2, eds R. W. Weaver, J. S. Angle, P. J. Bottomley, D. F. Bezdicek, M. S. Smith, M. A. Tabatabai, and A. G. Wollum (Madison, WI: Soil Science Society of America), 985-1018.

Hedin, L. O., von Fisher, J., Ostrom, N., Kennedy, B. P., Brown, M. G., and Robertson, G. P. (1998). Thermodynamics constraints on nitrogen transformation and other biogeochemical processes at soil-stream interfaces. Ecology 79, 684-703. doi: 10.2307/176963

Hefting, M., Clément, J. C., Dowrick, D., Cosandey, A. C., Bernal, S., Cimpian, C., et al. (2004). Controls of nitrification and denitrification in riparian soils along an European climatic gradient. Biogeochemistry 67, 113-134. doi: 10.1023/B:BIOG.0000015320.69868.33

Helton, A. M., Ardón, M., and Bernhardt, E. S. (2015). Thermodynamic constraints on the utility of ecological stoichiometry for explaining global biogeochemical patterns. Ecol. Lett. 18, 1049-1056. doi: 10.1111/ele.12487

Holmes, R. M., Jones, J. B., Fisher, S. G., and Grimm, N. B. (1996). Denitrification in a nitrogen-limited stream ecosystem. Biogeochemistry 33, 125-146. doi: 10.1007/BF02181035

Holmes, R. M., McClelland, J. W., Peterson, B. J., Tank, S. E., Bulygina, E., Eglinton, T. I., et al. (2012). Seasonal and annual fluxes of nutrients and organic matter from large rivers to the Arctic ocean and surrounding seas. Estuaries Coasts 35, 369-382. doi: 10.1007/s12237-011-9386-6

Houlton, B. Z., Sigman, D. M., and Hedin, L. O. (2006). Isotopic evidence for large gaseous nitrogen losses from tropical rainforests. Proc. Natl. Acad. Sci. U.S.A. 103, 8745-8750. doi: 10.1073/pnas.0510185103

Hynes, H. B. N. (1975). The stream and its valley. Verhandlungen Internationale Vereinigung für Theoretische und Angewandte Limnologie 19, 1-15.

Jacobs, T. C., and Gilliam, J. W. (1985). Riparian losses of nitrate from agricultural drainage waters. J. Environ. Qual. 14, 472-478. doi: $10.2134 /$ jeq1985.00472425001400040004x

Jones, J. B., Petrone, K. C., Finlay, J. C., Hinzman, L. D., and Bolton, W. R. (2005). Nitrogen loss from watersheds of interior Alaska underlain with discontinuous permafrost. Geophys. Res. Lett. 32:L02401. doi: 10.1029/2004GL021734

Junk, W. B., Bayley, P. B., and Sparks, R. E. (1989). The flood pulse concept in river-floodplain systems. Can. Spec. Publ. Fish. Aquat. Sci. 106, 110-127.

Kachenchart, B., Jones, D. L., Gajaseni, N., Edwards-Jones, G., and Limsakul, A. (2012). Seasonal nitrous oxide emissions from different land uses and their controlling factors in a tropical riparian ecosystem. Agric. Ecosyst. Environ. 158, 15-30. doi: 10.1016/j.agee.2012.05.008

Kiese, R., Hewett, B., and Butterbach-Bahl, K. (2008). Seasonal dynamic of gross nitrification and $\mathrm{N} 2 \mathrm{O}$ emission at two tropical rainforest sites in Queensland, Australia. Plant Soil 309, 105-117. doi: 10.1007/s11104-0079468-1

Kolbe, T., Marçais, J., Thomas, Z., De Dreuzy, J.-R., Rousseau-Gueutin, P., Aquilina, L., et al. (2016). Coupling 3D groundwater modeling with CFCbased age dating to classify local groundwater circulation in an unconfined crystalline aquifer. J. Hydrol. 543, 31-46. doi: 10.1016/j.jhydrol.2016. 05.020

Koyama, A., Stephan, K., and Kavanagh, K. L. (2012). Fire effects on gross inorganic $\mathrm{N}$ transformation in riparian soils in coniferous forests of central Idaho, USA: wildfires v. prescribed fires. Int. J. Wildland Fire 21, 69-78. doi: 10.1071/WF10132

Larouche, J., Abbott, B. W., Bowden, W. B., and Jones, J. B. (2015). The role of watershed characteristics, permafrost thaw, and wildfire on dissolved organic carbon biodegradability and water chemistry in Arctic headwater streams. Biogeosciences 12, 4221-4233. doi: 10.5194/bg-12-4221-2015

Leopold, L. B., Wolman, M. G., and Miller, J. P. (1964). Fluvial Processes in Geomorphology. San Francisco, CA: WH Freeman.

Likens, G. E. (1984). Beyond the shoreline: a watershed ecosystem approach. Verh. Int. Veering. Limnos. 22, 1-22. 
Likens, G. E., Bormans, F. H., Johnson, N. M., Fisher, D. W. and Pierce, R. C. (1970). Effects of forest cutting and herbicide treatment on nutrient budgets in the Hubbard Brook watershed-ecosystem. Ecol. Monogr. 40, 23-47. doi: $10.2307 / 1942440$

Lohse, K. A., Sanderman, J., and Amundson, R. (2013). Identifying sources and processes influencing nitrogen export to a small stream using dual isotopes of nitrate. Water Resour. Res. 49, 5715-5731. doi: 10.1002/wrcr.20439

Lowrance, R. R., Todd, R. L., and Asmussen, L. E. (1984). Nutrient cycling in an agricultural watershed: I. Phreatic movement. J. Environ. Qual. 13, 22-27. doi: 10.2134/jeq1984.00472425001300010004x

Lupon, A., Gerber, S., Sabater, F., and Bernal, S. (2015). Climate response of the soil nitrogen cycle in three forest types of a headwater Mediterranean catchment. J. Geophys. Res. Biogeosci. 120, 859-875. doi: 10.1002/2014JG002791

Lupon, A., Sabater, F., Miñarro, A., and Bernal, S. (2016). Contribution of pulses of soil nitrogen mineralization and nitrification to soil nitrogen availability in three Mediterranean forests. Eur. J. Soil Sci. 67, 303-313. doi: $10.1111 /$ ejss. 12344

Malone, E. T., Abbott, B. W., Klaar, M. J., Kidd, C., Sebilo, M., Milner, A. M., et al. (2018). Decline in ecosystem $\Delta 13 \mathrm{C}$ and midsuccessional nitrogen loss in a two-century postglacial chronosequence. Ecosystems doi: 10.1007/s10021-018-0245-1. [Epub ahead of print].

Matheson, F. E., Quinn, J. M., and Martin, M. L. (2012). Effects of irradiance on diel and seasonal patterns of nutrient uptake by stream periphyton. Freshw. Biol. 57, 1617-1630. doi: 10.1111/j.1365-2427.2012.02822.x

McClain, M. E., Boyer, E. W., Dent, C. L., Gergel, S. E., and Grimm, N. B. (2003). Biogeochemical hot spots and hot moments at the interface of terrestrial and aquatic ecosystems. Ecosystems 6, 301-312. doi: 10.1007/s10021-003-0161-9

McClain, M. E., Richey, J. E., and Pimentel, T. (1994). Groundwater nitrogen dynamics at the terrestrial-lotic interface of a small catchment in the Central Amazonian Basin. Biogeochemistry 27, 113-127. doi: 10.1007/BF00002814

McClelland, J. W., Holmes, R. M., Dunton, K. H., and Macdonald, R. W. (2012). The Arctic ocean estuary. Estuaries Coasts 35, 353-368. doi: 10.1007/s12237-010-9357-3

McMillan, R., Quideau, S. A., MacKenzie, M. D., and Biryukova, O. (2007). Nitrogen mineralization and microbial activity in oil sands reclaimed boreal forest soils. J. Environ. Qual. 36, 1470-1478. doi: 10.2134/jeq2006.0530

Minshall, G. W., Petersen, R. C., Cummins, K. W., Bott, G. L., Sedell, J. R., Cushing, C. E et al. (1983). Interbiome comparison of stream ecosystem dynamics. Ecol. Monogr. 53, 1-25. doi: 10.2307/1942585

Mitsch, W. J., and Gosselink, J. (2015). Wetlands. 5th Edn. London UK: John Wiley \& Sons.

Mu, C. C., Abbott, B. W., Zhao, Q., Su, H., Wang, S. F., Wu, Q. B., et al. (2017). Permafrost Collapse Shifts Alpine Tundra to a Carbon Source but Reduces N2O and CH4 Release on the Northern Qinghai, Tibetan Plateau. Geophys. Res. Lett. 44, 8945-8952. doi: 10.1002/2017GL074338

Naiman, R. J., and Décamps, H. (1990). The Ecology and Management of AquaticTerrestrial Ecotones. Paris: Man \& Biosphere Series.

Naiman, R. J., and Décamps, H. (1997). The ecology of interfaces: Riparian zones. Annu. Rev. Ecol. Syst. 28, 621-658. doi: 10.1146/annurev.ecolsys.28.1.621

Newbold, J. D., Elwood, J. W., O'Neill, R. V., and Sheldon, A. L. (1983). Phosphorus dynamics in a woodland stream ecosystem - A study of nutrient spiraling. Ecology 64, 1249-1265. doi: 10.2307/1937833

Newbold, J. D., Elwood, J. W., O'Neill, R. V., and Van Winkle, W. (1981). Measuring nutrient spiralling in streams. Can. J. Fish. Aquat. Sci. 38, 860-863. doi: 10.1139/f81-114

Noe, G. B., Hupp, C. R., and Rybicki, N. B. (2013). Hydrogeomorphology influences soil nitrogen and phosphorus mineralization in floodplain wetlands. Ecosystems 16, 75-94. doi: 10.1007/s10021-012-9597-0

Ocampo, C. J., Oldham, C. E., and Sivapalan, M. (2006). Nitrate attenuation in agricultural catchments: Shifting balances between transport and reaction. Water Resour. Res. 42:W01408. doi: 10.1029/2004WR003773

Oldham, C. E., Farrow, D. E., and Peiffer, S. (2013). A generalized Damköhler number for classifying material processing in hydrological systems. Hydrol. Earth Syst. Sci. 17, 1133-1148. doi: 10.5194/hess-17-1133-2013

Peterjohn, W. T., and Correll, D. L. (1984). Nutrient dynamics in an agricultural watershed: observations on the role of a riparian forest. Ecology 65, 1466-1475. doi: $10.2307 / 1939127$
Petrone, K. C., Jones, J. B., Hinzman, L. D., and Boone, R. D. (2006) Seasonal export of carbon, nitrogen, and major solutes from Alaskan catchments with discontinuous permafrost. J. Geophys. Res. 111:G04003. doi: 10.1029/2005JG000055

Pettorelli, N., Vik, J. O., Mysterud, A., Gaillard, J. M., Tucker, C. J., and Stenseth, N. C. (2005). Using the satellite-derived NDVI to assess ecological responses to environmental change. Trends Ecol. Evol. 20, 503-510. doi: 10.1016/j.tree.2005.05.011

Pinay, G., Black, V. J., Planty-Tabacchi, A. M., Gumiero, B., and Décamps, H. (2000). Geomorphic control of denitrification in large river floodplain soils. Biogeochemistry 50, 163-182. doi: 10.1023/A:1006317004639

Pinay, G., Clément, J. C., and Naiman, R. J. (2002). Basic principles and ecological consequences of changing water regime for nitrogen cycling in fluvial systems. Environ. Manage. 30, 481-491. doi: 10.1007/s00267-0022736-1

Pinay, G., Gumiero, B., Tabacchi, E., Gimenez, O., Tabacchi-Planty, A. M., Hefting, M. M., et al. (2007). Patterns of denitrification rates in European alluvial soils under various hydrological regimes. Freshw. Biol. 52, 252-266. doi: 10.1111/j.1365-2427.2006.01680.x

Pinay, G., Peiffer, S., De Dreuzy, J. R., Krause S., Hannah, D. M., Fleckenstein, J. H., et al. (2015). Upscaling nitrogen removal capacity from hot spot to the landscape. Ecosystems 18, 1101-1120. doi: 10.1007/s10021-015-9878-5

Pinay, G., Ruffinoni, C., and Fabre, A. (1995). Nitrogen cycling in two riparian forest soils under different geomorphic conditions. Biogeochemistry 30, 9-29. doi: $10.1007 / \mathrm{BF} 02181038$

Pinay, G., Ruffinoni, C., Wondzell, S., and Gazelle, F. (1998). Change in groundwater nitrate concentration in a large river floodplain: denitrification, uptake or mixing? J. N. Am. Benthol. Soc. 17, 179-189.

Poblador, S., Lupon, A., Sabaté, S., and Sabater, F. (2017). Soil water content drives spatiotemporal patterns of $\mathrm{CO}_{2}$ and $\mathrm{N}_{2} \mathrm{O}$ emissions from a Mediterranean riparian forest soil. Biogeosciences 14:4195. doi: 10.5194/bg-14-41 95-2017

Purwanto, B. H., Watanabe, A., Shoon, J. F., Kakuda, K., and Ando, H. (2005). Kinetic parameters of gross $\mathrm{N}$ mineralization of peat soils as related to the composition of soil organic matter. Soil Sci. Plant Nutr. 51, 109-115. doi: 10.1111/j.1747-0765.2005.tb00013.x

Raymond, P. A., Hartmann, J., Lauerwald, R., Sobek, S., McDonald, C., Hoover, M., et al. (2013). Global carbon dioxide emissions from inland waters. Nature 503, 355-359. doi: 10.1038/nature 12760

Raymond, P. A., Saiers, J. E., and Sobczak, W. V. (2016). Hydrological and biogeochemical controls on watershed dissolved organic matter transport: pulse-shunt concept. Ecology 97, 5-16. doi: 10.1890/14-1684.1

Rosemond, A. D., Benstead, J. P., Bumpers, P. M., Gulis, V., Kominoski, J. S., Manning, D. W., et al. (2015). Experimental nutrient additions accelerate terrestrial carbon loss from stream ecosystems. Science 347, 1142-1145. doi: 10.1126/science.aaa1958

Ross, D. S., Frediksen, G., Jamison, A. E., Wemple, B. C., Bailey, S. W. Shanley, J. B., et al. (2006). One-day rate measurement for estimating net nitrification potential in humid forest soils. For. Ecol. Manage. 230, 91-95. doi: 10.1016/j.foreco.2006.04.022

Ross, D. S., Shanley, J. B., Campbell, J. L., Lawrence, G. B., Bailey, S. W., Likens, G. E., et al. (2012). Spatial patterns of soil nitrification and nitrate export from forested headwaters in the northeastern United States. J. Geophys. Res. 117, 1-14. doi: 10.1029/2011JG001740

Ruess, R. W., Anderson, M. D., McFarland, J. M., Kielland, K., Olson, K., and Taylor, D. L. (2013). Ecosystem-level consequences of symbiont partnerships in an N-fixing shrub from interior Alaskan floodplains. Ecol. Monogr. 83, 177-194.

Sabater, S., Butturini, A., Clément, J. C., Burt, T., Dowrick, D., Hefting, M., et al. (2003). Nitrogen removal by riparian buffers under various $N$ loads along a European climatic gradient: patterns and factors of variation. Ecosystems 6, 20-30. doi: 10.1007/s10021-002-0183-8

Schade, J. D., and Hobbie, S. E. (2005). Spatial and temporal variation in islands of fertility in the Sonoran Desert. Biogeochemistry 73, 541-553. doi: $10.1007 /$ s10533-004-1718-1

Schimel, J. P., and Bennett, J. (2004). Nitrogen mineralization: challenges of a changing paradigm. Ecology 85, 591-602. doi: 10.1890/03-8002 
Sébilo, M., Mariotti, A., Mayer, B., Pinay, G., and Mariotti, A. (2013). Long term release of nitrate from agricultural plant-soil system. Proc. Natl. Acad. Sci. U.S.A. 110, 18185-18189. doi: 10.1073/pnas.1305372110

Seitzinger, S. P., Mayorga, E., Bouwman, A. F., Kroeze, C., Beusen, A. H. W., Billen, G., et al. (2010). Global river nutrient export: a scenario analysis of past and future trends. Global Biogeochem. Cycles 24:GB0A08. doi: 10.1029/2009GB003587

Shah, J. J. F., and Dahm, C. N. (2008). Flood regime and leaf fall determine soil inorganic nitrogen dynamics in semiarid riparian forests. Ecol. Appl. 18, 771-788. doi: 10.1890/07-0447.1

Shaw, M. R., and Harte, J. (2001). Response of nitrogen cycling to simulated climate change: differential responses along a subalpine ecotone. Glob. Chang. Biol. 7, 193-210. doi: 10.1046/j.1365-2486.2001.00390.x

Smith, M., Conte, P., Berns, A. E., Thomson, J. R., and Cavagnaro, T. R. (2012). Spatial patterns of, and environmental controls on, soil properties at a riparian-paddock interface. Soil Biol. Biochem. 49, 38-45. doi: 10.1016/j.soilbio.2012.02.007

Sotta, E. D., Corre, M. D., and Veldkamp, E. (2008). Differing N status and $\mathrm{N}$ retention processes of soils under old-growth lowland forest in Eastern Amazonia, Caxiuanã, Brazil. Soil Biol. Biochem. 40, 740-750. doi: 10.1016/j.soilbio.2007.10.009

Stark J. M., and Hart, S. C. (1997). High rates of nitrification and nitrate turnover in undisturbed coniferous forests. Nature 385, 61-64. doi: 10.1038/385 $061 \mathrm{a} 0$

Stark, J. M., and Norton, J. M. (2015). The invasive annual cheatgrass increases nitrogen availability in 24-year-old replicated field plots. Oecologia 177, 799-809. doi: 10.1007/s00442-014-3093-5

Steffen, W., Richardson, K., Rockström, J., Cornell, S. E., Fetzer, I., Bennett, E. M., et al. (2015). Planetary boundaries: guiding human development on a changing planet. Science 347:1259855. doi: 10.1126/science. 1259855

Swanson, T. J., Carrie, T. K., and Woodmansee, R. G. (1988). Landform effects on ecosystem patterns and processes. Bioscience 38, 92-98.

Tabacchi, E., Correll, D., Hauer, R., Pinay, G., Planty-Tabacchi, A.-M., Wissmar, R. C. (1998). Development, maintenance and role of riparian vegetation in the landscape. Freshw. Biol. 40, 497-516. doi: 10.1046/j.1365-2427.1998.0 0381.x

Taylor, D. L. (2013). Ecosystem-level consequences of symbiont partnerships in an $\mathrm{N}$-fixing shrub from interior Alaskan floodplains. Ecol. Monogr. 83, 177-194. doi: 10.1890/12-0782.1

Taylor, P. G., and Townsend, A. R. (2010). Stoichiometric control of organic carbon-nitrate relationships from soils to the sea. Nature 464, 1178-1181. doi: $10.1038 /$ nature 08985
Thomas, Z., Abbott, B. W., Troccaz, O., Baudry, J., and Pinay, G. (2016). Proximate and ultimate controls on carbon and nutrient dynamics of small agricultural catchments. Biogeosciences 13, 1863-1875. doi: 10.5194/bg-13-1863-2016

Tiwari, T., Buffam, I., Sponseller, R. A., Laudon, H. (2017). Inferring scale dependent processes influencing stream water biogeochemistry from headwater to sea. Limnos. Oceanogr. 62, S58-S70. doi: 10.1002/lno.10738

Van Cleve, K., Yarie, J., Erickson, R., and Dyrness, C. T. (1993). Nitrogen mineralization and nitrification in successional ecosystems on the Tanana River floodplain, interior Alaska. Can. J. Forest Res. 23, 970-978. doi: 10.1139/x93-125

Van Meter, K. J., and Basu, N. B. (2017). Time lags in watershed-scale nutrient transport: an exploration of dominant controls. Environ. Res. Lett. 12, 1-12. doi: 10.1088/1748-9326/aa7bf4

Vannote, R. L., Minshall, G. W., Cummins, K. W., Sedell, J. R., and Cushing, C. E. (1980). The river continuum concept. Can. J. Fish. Aquat. Sci. 37, 130-137.

Vitousek, P. M., and Field, C. B. (1999). Ecosystem constraints to symbiotic nitrogen fixers: a simple model and its implications. Biogeochemistry 46, 179-202.

Voigt, C., Marushchak, M. E., Lamprecht, R. E., Jackowicz-Korczynski, M. Lindgren, A., Mastepanov, M., et al. (2017). Increased nitrous oxide emissions from arctic peatlands after permafrost thaw. Proc. Natl. Acad. Sci. U.S.A. 114, 6238-6243. doi: 10.1073/pnas.1702902114

Wallace, J. B., Eggert, S. L., Meyer, J. L., and Webster, J. R. (2015). Stream invertebrate productivity linked to forest subsidies: 37 stream-years of reference and experimental data. Ecology 96, 1213-1228. doi: 10.1890/14-1589.1

Webster, J. R. (1975). Analysis of Potassium and Calcium Dynamics in Stream Ecosystems on Three Southern Appalachian Watersheds of Contrasting Vegetation. Dissertation, University of Georgia, Athens.

Wray, H. E., and Bayley, S. E. (2008). Nitrogen dynamics in floating and nonfloating peatlands in the Western Boreal Plain. Can. J. Soil Sci. 88, 697-708. doi: $10.4141 /$ CJSS07055

Conflict of Interest Statement: The authors declare that the research was conducted in the absence of any commercial or financial relationships that could be construed as a potential conflict of interest.

Copyright (C) 2018 Pinay, Bernal, Abbott, Lupon, Marti, Sabater and Krause. This is an open-access article distributed under the terms of the Creative Commons Attribution License (CC BY). The use, distribution or reproduction in other forums is permitted, provided the original author(s) and the copyright owner are credited and that the original publication in this journal is cited, in accordance with accepted academic practice. No use, distribution or reproduction is permitted which does not comply with these terms. 